\title{
PLAG1 wt Allele
}

National Cancer Institute

\section{Source}

National Cancer Institute. PLAG1 wt Allele. NCI Thesaurus. Code C71424.

Human PLAG1 wild-type allele is located in the vicinity of $8 q 12$ and is approximately $50 \mathrm{~kb}$ in length. This allele, which encodes zinc finger protein PLAG1, plays a role in cellular proliferation. Mutation or translocation of this gene is associated with hepatoblastoma, lipoblastoma and salivary gland pleiomorphic adenomas. 